\title{
FARKLI ÜLKE UYGULAMALARINDA YARGISAL EMİR
}

\section{Burcu ERDINNÇ,***,***}

\section{$\ddot{O} Z$}

Yargisal emir, Türk pozitif hukukunda yer almayan bir müessesedir. Ancak tanımlanması itibariyle Türk yargllama sisteminde yer alan birtakım yargl kararlarının yargısal emir niteliğinde olduğu savunulabilir. Mahkemenin idareye emir vermesi anlamına gelen yargısal emir müessesesi, Ingiliz hukuku kökenlidir. Bugün itibariyle hem Anglosakson hukuk sisteminde hem de Kita Avrupası hukuk sisteminde uygulanmaktadır. Ingiltere, Amerika Birleşik Devletleri, Fransa, Almanya, Ísveç, Italya gibi pek çok ülkede var olan bir müessesedir. Türk hukuku bakımından tartışılması, yargı kararlarının uygulanmasını sağlayıcı rolü sebebiyledir. Doktrinde bu yönüyle ele alınmıştır. Çalışmamız, yargı kararlarının uygulanmasını sağlayıcı yönü dışında yargı kararlarının somutlaştırılması bakımından da yargısal emirin önemini vurgulamaktadır. Yargisal emir hem yargı kararlarının uygulanmamasinı engelleyecek hem de yargı kararlarının somutlaşarak daha doğru uygulanmasını sağlayacaktır. Nihayetinde bu iki yönüyle birlikte yargisal emir hukuk devleti ilkesine hizmet edecektir. Çalışmamızda yargısal emrin farklı ülke örnekleri tanıtılacaktır. Ingiltere, Amerika Birleşik Devletleri, Fransa ve Italya ele alınacak ülkelerdir. Bu uygulamalar incelenerek yargisal emirin anlamı, uygulanma biçimleri ortaya konulacaktır. Böylece Türk hukuk uygulamasında bu tür bir müessesenin var olup olmadı̆̆ ile var olup olamayacă̆ konuları değerlendirilebilecektir.

Anahtar Kelimeler: Yargisal emir, Yargisal denetim, Hukuk devleti ilkesi, Kuvvetler ayrılı̆̆ ilkesi, Yargı kararlarının uygulanmaması.

\section{INJUNCTION IN DIFFERENT COUNTRY IMPLEMENTATIONS}

\section{ABSTRACT}

Injunction is an institution that does not have a place in Turkish positive law. However, as regards definition, it can be defended that some judicial decisions included in the Turkish judicial system have the attribute of injunction. The institution of injunction, which has the meaning of giving orders to the administration of the

* Arş. Gör. Dr. , İnönü Üniversitesi Hukuk Fakültesi İdare Hukuku Anabilim Dalı / MALATYA e-posta: burcu.erdinc@inonu.edu.tr

ORCID: https://orcid.org/0000-0003-4103-0321

** Bu çalışma, İnönü Üniversitesi BAP Koordinasyon Birimi tarafindan desteklenmiştir.

*** Bu çalışma, Gazi Üniversitesi Sosyal Bilimler Estitüsü’nde yürütülen "Yargısal Emir Kavramı ve Türk Hukuk Uygulamasındaki Yansımaları" adlı doktora tezinden üretilmiştir. DOI : 10.34246/ahbvuhfd.1018884

Yayın Kuruluna Ulaştığı Tarih $\quad$ : 27/07/2021

Yayınlanmasının Uygun Görüldüğü Tarih: 15/09/2021 
court, is of British legal origin. As of the present-day, it is implemented both in the Anglo-Saxon legal system and in the Continental European legal system. It is an institution that exists in many countries, such as England, the United States of America, France, Germany, Sweden and Italy. It is based on the provider role for the debating and implementing the judiciary decisions from the aspect of Turkish law. It has been treated from this aspect in the doctrine. Our study also emphasizes the importance of injunction from the aspect of concretizing the judicial decisions outside of the provider aspect of the implementation of judicial decisions. Injunction would both prevent judicial decisions not being implemented and by concretizing the judicial decisions, it would provide for a more accurate implementation. Ultimately, injunction together with these two aspects would serve the principles of the state of law. In our study, injunction will be presented with different country examples. England, the United States of America, France and Italy are the countries that will be treated. The meaning of injunction and the forms of application will be set forth by studying in detail these implementations. In this manner, it will be possible to evaluate the subjects of whether this type of institution exists or not in the Turkish legal implementations and whether it should or should not exist.

Keywords: Injunction, Judicial supervision, Principle of the state of law, Principle of the separation of powers, Not implementing judicial decisions.

\section{GİRIŞ}

İdareye yarg1 organları tarafından emir verilmesi anlamına gelen yarg1sal emir, Anayasa'da yer alan yürütme görevinin kanunlarda gösterilen şekil ve esaslara uygun olarak yerine getirilmesini kısıtlayacak, idari eylem ve işlem niteliğinde mahkeme kararı verilemeyeceği hükmü (md. 125) sebebiyle doktrinde yasaklı bir uygulama olarak değerlendirilmiştir. ${ }^{1}$ Ancak yargısal

1 Ragıp Sarıca, İdari Kaza, IÜHF Talebe Cemiyeti Yayınları, İstanbul, 1942, s. 263; Turgut Candan, "İdari Yarg1 Kararlarının Uygulanması-IV",1991, (256), Maliye Postası Dergisi, s. 46; Karşıt görüş için bkz. Yıldırım Uler, İdari Yargıda İptal Kararlarının Sonuçları, AÜHF Yayınları, 1970, s. 115; Sait Güran, “Anayasa'nın Kuvvetler Ayrılığı İlkesine ve Yönetim Yargı İlişkilerine Bakış Açısında Değişiklik”, 1994, 11, Anayasa Yargısı Dergisi, s. 199 vd; “... iptal kararlarl ortadan kaldirlldiklar idari tasarrufun yerine kaim olmaylp sadece idareyi eski karar yerine yeni bir karar almaya mecbur birakır. Mesela bir ruhsat telebinin reddi üzerine bu red kararına karşı bir iptal davası açılması ve red kararının iptali halinde, bu red kararinin iptali ruhsatname yerine kaim olmaz ve ruhsatı tazammun etmez; sadece idareyi ruhsat hususunda yeni bir karar vermeğe mecbur birakır. İtal kararl, idareye alınacak karar hakkında bir direktif de vermez." Siddık Sami Onar, İdare Hukukunun Umumi Esasları, Cilt III, 3. Bası, İsmail Akgün Matbaası, 1966, s. 1790. 
emir müessesesi, ilgili Anayasa hükmü kapsamında yer almayan, yasaklı olmayan, bu denli dar bir anlama hapsedilemeyecek kadar derin bir husustur. Mahkeme kararlarının uygulanmasının sağlanması fonksiyonu üstlenen müessese, söz konusu anayasal hükme aykırılık içermemektedir.

Kanuni çerçevede takdir yetkisine sahip ve kamu gücüyle donatılmış bir idarenin bulunduğu idari rejim sisteminde ${ }^{2}$, yargısal emir müessesesinin kabulü önem arz eder. İdare ile yargı organı arasındaki ayrılık ihlal edilmemesi gerektiğinden, bu kabul, muhkem temellere dayanmalıdır. Anayasal bir ilke olan hukuk devleti ilkesinin (md. 2) gereği olarak gerçekleştirilecek yargısal denetim, kuvvetler ayrılığ 1 ilkesine zarar vermeyecek nitelikte olmalıdır.

Usulüne bakıldığında, yargısal emir, mahkemeler tarafından idareye emir verilmesi gibi gözükse de aslolan mahkemelerin bu nitelikteki kararlarıyla idareleri hukuka uygun davranmaya sevk etmesi ve hatta zorlamasıdır. Hukuk devleti ilkesi gereği ${ }^{3}$, mahkeme kararları, uygulanmaları yönünde bir emri mündemiçtir. $\mathrm{Bu}$ nedenle yargısal emir müessesesine mahkeme kararlarının uygulanmasını sağlayıcı bir işlev yüklemek aslında hukuk devleti ilkesiyle bağdaşmayacaktır. Hukuk devletinde mahkeme kararlarının uygulanmaması gibi bir sorunun bulunmaması gerekir. Ancak maalesef bu ifademiz olması gereken hukuk anlayışı bakımındandır. Oysa ki olan hukuk anlayışı, mahkeme kararlarının uygulanmasını sağlayıcı birtakım tedbirlerin ayrıca alınmasını gerektirmektedir.

Yargısal emir, mahkemeler tarafından idarelere karşı verilen ve uyulması, gereklerinin yerine getirilmesi zorunlu olan kararlardır. ${ }^{4}$ Türlerine göre; bazen

2 İl Han Özay, Günışığında Yönetim II Yargısal Korunma, On İki Levha Yayıncılık, 2010, s. 4 vd; Şeref Gözübüyük/Turgut Tan, İdare Hukuku, Cilt I, 13. Bask1, Turhan Kitabevi, 2019, s. 8; Lütfi Duran, İdare Hukuku Ders Notları, Fakülteler Matbaası, 1982, s. 15 vd; Bahtiyar Akyılmaz/Murat Sezginer/Cemil Kaya, Türk İdare Hukuku, 10. Bask1, Savaş Yayınc1lık, 2019, s. 59 vd; Metin Günday, İdare Hukuku, 10. Baskı, İmaj Yayınevi, 2011, s. 24; Gözübüyük, idari hukuku sistemlerini, yargı birliği sistemi ve yönetsel yargı sistemi biçiminde adlandırmaktadır. Şeref Gözübüyük, Yönetsel Yarg1, 35. Bası, Turhan Kitabevi, 2016, s. 3 vd; Onur Karahanoğulları, İdarenin Hukukla Kavranması: Yasallık ve İdari İşlemler (Yargı Kararlarına Dayalı Bir İnceleme), 3. Bası, Turhan Kitabevi, 2015, s. 9 vd.

3 Hukuk devleti ilkesi, maddi ve şekli unsurlardan oluşmaktadır. Hukuk devleti ilkesinin şekli unsurlarından biri idarenin kanuniliğidir. Bu unsur kapsamında, mahkeme kararlarının uygulanması idarenin bağlı yetkisi içinde yer almaktadır. Akyılmaz/Sezginer/Kaya, İdare Hukuku, s. 79 vd ve s. 115.

4 Adem Avc1, "İngiliz Hukukunda Mandamus (Mandatory Order) İlkesi”, 2014, 4(2), Hacettepe Hukuk Fakültesi Dergisi, s. 166; Hasan Nuri Yaşar, İdari Yargı Kararlarının Etkinleştirilmesi Arayışında İdari Yargı İdari Yargıç Yargısal Emir, Tıpkı Basım, On İki 
bir işlemin iptalini emreden, bazen bir işlem ya da eylemin yapılmasını yasaklayan ve bazen de olumlu ya da olumsuz bir emir içeren kararlardır. Bunların yanı sıra, yargısal emirler kamu görevlilerinin görevlerini yerine getirmesi yönünde zorlayıcı emirler de içerebilmektedir. Ülkeler bazında incelendiğinde, örneğin Fransa'da "idari hâkimin kararlarıyla idari eylemi başlatması" şeklinde bir yargısal emir türü de mevcuttur. ${ }^{5}$ Kanaatimizce, bu uygulamayla yargısal emrin ötesine geçen ve artık idarenin görev alanına müdahalede bulunan bir yetki söz konusudur.

Yargısal emir, hukuk devleti ilkesini gerçekleştirmenin vazgeçilmez bir unsuru olan idarenin yargısal denetimi kapsamında değerlendirilebilecek bir başvuru imkânıdır. Yargısal denetim sayesinde idarenin işlem ve eylemlerinin keyfi olmaması, muhakkak hukuki bir sebebe dayanması sağlanmaktadır. Yargısal emir müessesesiyle de idarenin hukuku uygulamaktan kaçınma firsatı engellenmektedir. Mahkemenin yaptığ 1 kesinlikle bir yerindelik denetimi değildir. Tamamen hukukilik denetimi içerisinde kalan bir değerlendirmedir ve idareye hukuka uygun bir yol göstermeyi hedeflemektedir.

Tarihçesine bakıldığında, yargısal emir, Anglosakson hukuk sisteminde ortaya çıkmış ve zamanla Kıta Avrupası hukuk sisteminde uygulanmaya başlanmıştır. Birbirinden ayrı kurallara sahip olan bu hukuk sistemlerinde aynı hukuki kurumun -yargısal emrin- uygulanması mümkündür. Belirtmek gerekir ki, amaçları hukuk devletini gerçekleştirmek ve korumak olduğunda, temel ilkelerle çatışmamak kaydıyla, farklı hukuk sistemlerinin bir diğerine özgü hukuki müesseselerden faydalanmasında sakınca yoktur. Yargısal emir de bu nitelikte bir hukuki müessesedir.

Yargısal emir kavramının kökeninde, idarenin sorumluluğunun kabul edilmediği dönemlerde zarar gören kişinin, zararına sebep olan idare görevlisini mahkeme önüne çıkarmasına imkân tanıyan writler (kral fermanları) yer almaktadır. ${ }^{6}$ Kral tarafindan, kamusal alanda görevli olan

Levha Yayınc1lik, 2013, s. 161 vd.

5 Aktaran YAŞAR, s. 172.

6 Paul Craig, Administrative Law, 8th Edition, Sweet\&Maxwell, 2016, s. 793 vd; Hafize Sevinç Aydar, İngiliz Hukukunda Yargısal Emir Kavramı ve Türkiye'de Uygulanabilirliği, Yayımlanmamış Doktora Tezi, Anadolu Üniversitesi Sosyal Bilimler Enstitüsü, 2008, s. 2 vd; Avc1, s. 185; Süleyman Kurt, "Britanya İdari Yarg1 Yerleri (Tribunal Sistem) ve Yargisal Denetim", 2004, (107), Danıştay Dergisi, s. 105 vd; "Writ” kavramına 1215 tarihli Magna Carta'da da rastlanmaktadır. Magna Carta'nın 34. ve 36. maddelerinde, kral fermanlarından yani writlerden söz edilmektedir. Bkz. The Magna Carta (Great Charter), <https://www. 
bireyleri, görevlerini gerektiği gibi yerine getirmeye zorlama ve sahip oldukları yetkileri kötüye kullanmalarını engelleme amaciyla verilen kararlar writ olarak adlandırılmaktayd $1 .{ }^{7}$ Writler, idarenin yargısal denetimini sağlayan araçlard1.

Yargısal emrin kökeni olan writler, ayrıcalıklı emirler ve ayrıcalıklı olmayan emirler olarak ikiye ayrılmaktadır. ${ }^{8}$ Ayrıcalıklı emirler; certiorari, habeas corpus, mandamus ve prohibition türlerinden oluşmaktadır. ${ }^{9} \mathrm{Bu}$ adlandırmalar ortaya çıktıkları döneme aittir. Günümüzde kanunlarda yeni ifadeleriyle yer almaktadırlar. ${ }^{10}$ Ayrıcalıklı olmayan emirler ise; injunction ve decleration'dur. ${ }^{11}$ Yalnızca kamu hukuku alanında uygulanan emirler ayrıcalıklı olarak adlandırılmaktaydı. Bunlar kraliyet kaynaklı olup, kraliyete karşı kullanılamamaktaydı. ${ }^{12}$

Yargısal emrin ortaya çıktığı İngiliz hukuk sisteminde, Common law ve Equity hukuku söz konusuydu. ${ }^{13}$ Equity hukuku, Common law'un dava açabilmek için bir writ gerektirmesi ve emsal kararların çeşitlenmemesinden

constitution.org/eng/magnacar.pdf $>$ Erişim Tarihi: 20 Ocak 2021.

7 Writ, devlet ya da yetkili yasal merciler adına, yapılması gerekeni ya da belirli bazı hareketlerin yapılmasından kaçınılmasını bildiren, mahkemeye ait yazılı emirdir. writlerin kökeni, kralın insanlara ve mahkemelere emirlerini ilettiği bir yöntem olarak Anglosakson sisteminde karşımıza çıkar. Kral tarafından, kamusal işlerle görevli olanları görevlerini gerektiği gibi yerine getirmeye zorlamak ve sahip oldukları yetkileri kötüye kullanmalarını engellemek amacıyla verilen kararlardır. Kurt, s. 105 vd; Sırrı Düğer, Anglosakson Hukuk Sisteminde İdarenin Yargısal Denetimi, Yetkin Yayınları, Mart 2019, s. 180.

8 Ayrıcalıklı emirler, kamu hukukunda söz konusu olan emirleri ifade etmekte iken, ayrıcalıklı olmayan emirler özel hukuk alanında söz konusu olan injunction ve decleration emirlerini ifade etmektedir. Bryan A. Garner, Black Law Dictionary, 10th Edition, Thomson Reuters, 2014, s. $1845 \mathrm{vd}$.

9 Garner, s. 1845; Kurt, Habeas Corpus'u bu kapsamda saymamaktadır. Bkz. Kurt, s. 105 vd.

10 Kanunda yer alan adlandırmalar şöyledir: Certiorari "quashing order", mandamus "mandatory order" ve prohibition "prohibiting order". Kanun maddesi için bkz. $<$ http:// www.legislation.gov.uk/ukpga/2007/15/section/15> Erişim Tarihi: 20 Ocak 2021.

11 Kurt, s. 106 vd.

12 Ergun Özbudun, "İngiliz Hukukunda Hükümet Tasarrufları”, 1961, 18(1), Ankara Üniversitesi Hukuk Fakültesi Dergisi, s. 340 vd.

13 Equity hukuku hakkında bilgi için bkz. Cem Eroğul, Çağdaş Devlet Düzenleri, 10. Bask1, İmaj Yayınevi, 2016, s. 39 vd; Uğur Mumcu, "İngiliz Hukukunda Ultra Vires Kavramı", 1970, XXVII, Ankara Üniversitesi Hukuk Fakültesi Dergisi, s. 41 vd; Bahadır Kılınç, "Common Law (Ortak Hukuk) Sistemine Sahip Ülkelerden A.B.D. ve İngiltere'de Anayasa Kavramı Ve Yargısal Denetim”, Anayasa Yargısı İncelemeleri-1, Anayasa Mahkemesi Yayınları, 2006, s. 116. 
dolayı adaleti sağlamada yetersiz kalması nedeniyle oluşmuştur. Yargısal emir kavramı, nasafet (hakkaniyet) kurallarına göre işleyen Equity hukukunu uygulayan mahkemelerce geliştirilmeye başlanmıştır. ${ }^{14}$

Writ kavramı, yargısal emir müessesesinin esas amaçlarını bize göstermektedir. Bu amaçlar kamu görevlerinin gerektiği gibi yerine getirilmesi ve bireylerin hukuki güvenliğinin sağlanmasıdır. Bu amaçların saptanması, farklı hukuk sistemlerinde müessesenin yer alabilirliğini ve uygulama biçimini belirlemede yol gösterici olacaktır.

Yargısal emrin farklı ülkelerde yer alan uygulamalarının çalışılması ve doğru anlaşılması müessesenin özünü kavramak açısından faydalı olacaktır. Öte yandan bu inceleme sonucu Türk hukukunda müessesenin uygulanıp uygulanamayacağına ilişkin değerlendirmeler yapılması da mümkün olacaktır. ${ }^{15}$ Hukuk devleti ilkesine hizmet etmesine rağmen, ülkemizde yasak olarak nitelendirilen ${ }^{16}$ yargısal emre yakından bakmak, kanaatimizce bir gerekliliktir.

\section{I. İNGILTERE'DE YARGISAL EMIR}

1982 tarihinden bu yana, İngiltere' $\mathrm{de}^{17}$ idare hukuku $^{18}$, High Court'un Queen's Bench Division'unda geliştirilmekteydi. ${ }^{19}$ İdare hukuku konusunda

14 Eroğul, s. 40.

15 Bu yönde bir tez çalışması tarafımızdan yürütülmektedir.

16 Bkz. Dipnot 1.

17 İngiltere'de idari mahkemelerin gelişim sürecine ilişkin bilgi için bkz. Turgut Candan, "Britanya İdari Mahkemeleri”, 1992, (4), Türkiye Barolar Birliği Dergisi, s. 485 vd. İlgili kaynakta ilginç bir bilgi yer almaktadır: "İdari mahkemeler -adli mahkemelerden farklı olarak- emsal kararlarla kesinlikle bağlı değildirler.” Bu farklılık dikkat çekicidir. Candan, "Britanya", s. 496.

18 İngiltere'de idare hukuku, ayrı bir idari yargı örgütü tarafından geliştirilmemiştir. 2000'li yıllara kadar genel mahkemelerde gelişen idare hukuku, 2000 yılında, o zamanki ifadesiyle High Court'ta Administrative Court (İdari Mahkeme) adıyla ayrı bir daire kurulmasiyla birlikte gelişimini bu mahkemelerde devam ettirdi. 2007 y1lında ise "Tribunal, Courts and Enforcement Act" ile mahkemelerde radikal yenilemeler gerçekleştirildi. Mahkemelerin oluşumu ve mahkemelerde uygulanan usuller bakımından geniş kapsamlı değişiklikler yapıld1. Bkz. Craig, s. 231 vd.

19 Esin Örücü, "Büyük Britanya'da İdarenin Yargısal Denetimi”, II. Ulusal İdare Hukuku Kongresi, İdari Yargının Dünyadaki Bugünkü Yeri, 1993, s. 258; Gözübüyük/Tan, İngiltere'de, mahkemelerde gelişme sürecinden önce, 1958 yılında "Tribunal and Enquires Act"ın kabulüyle İdare hukukunun gelişmeye başladığından bahsetmektedir. Bkz. Gözübüyük/Tan, s. 8. 
atılan önemli bir adım, 2000 yılında High Court'ta Administrative Court adıyla bir daire kurulması olmuştur. ${ }^{20}$ İngiltere'de ayrı bir idari yargı düzeni olmasa da, idari işlere özgü bir dairenin kurulmuş olması ve idari işlemleri denetleyen ilk derece mahkemelerinin varlığı, idare hukuku bakımından önemli gelişmelerdir. $\mathrm{Bu}$ dairelerde, idare hukuku alanında uzmanlaşmış kişiler kararlar almakta ve idari uyuşmazlıkları çözmektedirler.

Anglosakson hukuk sisteminde, mahkeme kararları ve kanuni düzenlemeler hukuk kurallarını oluşturmaktadır. ${ }^{21}$ Geleneksel İngiliz hukuk sisteminin temel özelliği olarak ise, mahkeme kararları tek başına büyük önem taşımaktadır. Her bir mahkeme, yargılama yaparken kendi kararları yanında diğer mahkeme kararlarını dikkate almak zorundadır. Mahkeme kararları doğrultusunda gelişen bir hukuk sistemi söz konusudur. Bu özellik, mahkemelere ait yargısal emir kararları ile idarenin yönlendirilebilmesini anlamlı k1lmaktadır.

Günümüzde yargısal emir uygulamasına ilişkin düzenlemeler "Yüksek Mahkeme Kanunu (Senior Court Act)" md. 31'de yer almaktadır. ${ }^{22}$ Maddeye göre; yargısal denetim kapsamındaki yargısal emir talepleri Yüksek mahkemeye yöneltilecektir. Herhangi bir yargısal emrin verilip verilmeyeceği hâkimin takdirindedir. Yeterli menfaat koşulu gerçekleşmediği müddetçe mahkeme yargısal emir başvurusu için kişiye izin vermeyecektir. Üçüncü fikranın alt bentlerinde belirtildiği üzere; mahkeme, davaya neden olan işlem gerçekleşmeseydi ortaya çıkan sonuç değişmeyecekse yargısal emre hükmetmeyecektir. Ayrıca mahkeme bu yönde karar alırken kamu yararını da göz önünde bulunduracaktır. Söz konusu işlem gerçekleşmediğinde sonuç değişmese bile, kamu yararının gerektirmesi halinde hâkim yargısal emre hükmedebilecektir. Dördüncü fikraya göre; mahkeme talep bulunması halinde başvurana tazminat ödenmesine, tazminin sağlanmasına veya eski halin iadesine ${ }^{23}$ karar verebilir.

20 Eroğul, s. 46.

21 Eroğul, s. 36; Kılınç, s. 115; Bugün hukukun iki kaynağından biri olan mahkeme kararları; 19. yüzyılın son çeyreğinden itibaren Common Law ve Equity hukukunun birleşmesinden oluşmaktadır. Bkz. Eroğul, s. 36.

22 Kanun metni için bkz. < http://www.legislation.gov.uk/ukpga/1981/54/section/31>, Erişim Tarihi: 20 Ocak 2021.

23 "Eski halin iadesi” olarak ifade ettiğimiz aslında "ödenmesi gereken meblağın geri ödenmesini" ifade etmektedir. Bizim hukukumuz bakımından bu şekilde ifade edilmesini tercih ettik. Belirtmek gerekir ki; eski hale getirme Fransız hukukunda da sadece ödenmesi gereken meblağın geri ödenmesi şeklinde değildir. Jeangirard-Dufal tarafından verilen somut 
Maddenin beşinci fikrasına göre; başvurunun kaynaklandığı mahkeme kararı Yüksek Mahkeme'nin bozması halinde kararı veren mahkemeye ya da idareye gönderilebilir ya da Yüksek Mahkeme kendisi ilgili konuda karar verebilir. Yüksek Mahkeme tarafindan yeniden bir karar verilebilmesinin birtakım şartları fikrada düzenlenmiştir: a. Karar bir mahkeme tarafından alınmış olmalıdır; b. Kararda hukuki bir hata bulunmalıdır; c. Söz konusu hukuki hata mevcut olmasaydı mahkemece alınacak karar tek olmalıdır. $\mathrm{Bu}$ durumlar gerçekleşir ise, Yüksek Mahkeme kendisi esas hakkında karar verebilir. Altıncı fikraya göre; mahkeme başvuruda gecikildiği kanaatindeyse yargısal emir talebini reddedebilir. Dolayısıyla düzenlemeye göre; yargısal emir başvurusunun, her somut olay açısından mahkemece belirlenecek makul bir süre içerisinde yapılması gerekir. Ayrıca bu hukuksal çareye başvurulması bir kişinin hakkına ciddi bir zarar verecekse, önemli boyutta hukuki bir zorluğa sebep olacaksa ya da iyi yönetim ilkelerine zarar verecekse mahkeme tarafından reddedilebilir. Yedinci fikraya göre ise; altıncı fikra hükmü, yargısal emir süre yönünden reddi hali, yargısal denetim başvuru süresini sınırlandıran herhangi bir mahkeme hükmünü engellemeyecektir.

Yargısal emir, birbirinden farklı içeriklere sahip türlere sahiptir. $\mathrm{Bu}$ emirler, mahkemeler tarafindan verilen ve yerine getirilmesi zorunlu olan kararları ifade etmektedir. Ancak bunlar kimi zaman işlemden önce verilerek önleyici olmakta, kimi zaman kamu görevlilerine görevlerini emrederek zorlayıcı nitelikte olmakta, kimi zaman ise işlemin iptalini emredip hukuka aykırılığı ortadan kaldırarak düzeltici olmaktadır. Her bir yargısal emir türü, başlı başına bir inceleme konusudur. Hukuk sistemlerinde edindikleri yerler, yaptıkları denetim ve sağladıkları hukuki koruma farklıdır. Geçirdikleri tarihsel süreçler ve günümüzde kazandıkları anlamlar -birbirleriyle bağlantılı olmakla birlikte- incelendiğinde, birebir aynı anlamda olduklarını savunmak mümkün değildir. Menşei İngiliz hukukunda, yargısal emrin güncel türleri "Mahkemeler ve İnfaz Kanunu (Tribunal, Courts and Enforcement Act 2007)"nda yer almaktadır. Kanunun Bölüm I, Madde 15 ve devamında yer alan türleri; mandatory order, prohibiting order, quashing order, declaration ve injunction'dır. ${ }^{24}$

olay örneğine göre; bir yargısal emir olarak kişinin görevine iade edilmesine hükmedilmiştir. Bkz. Claire Jeangırard-Dufal, "Le juge administratif et l'injonction: Expérience de vingt années d'application", 2015, (3), RFDA, s. $461 \mathrm{vd.}$

24 Kanun maddesi için bkz. <http://www.legislation.gov.uk/ukpga/2007/15/section/15>, Erişim Tarihi: 20 Ocak 2021. 
Mandatory order (mandamus; zorlayıcı emir), görevinden kaçınan bir kamu görevlisine, kaçındığı kamu görevinin ifasını emreden kararlardır. ${ }^{25}$ Kamu görevlilerini, yasal olarak yapması gerekenleri yapmaları için zorlamaktadır. ${ }^{26}$ Mevzuatın doğrudan bir şeyin yapılmasını emrettiği durumlarda verilebilecek bir emirdir. ${ }^{27} \mathrm{Bu}$ emirle, ilgili kamu görevlisi kanuna aykırı bir davranışa zorlanamaz. ${ }^{28}$ Mandamus ya da mandatory order adıyla anılan zorlayıcı emir, kamu hukuku kaynaklı yargısal emir türlerinden biridir. Kral fermanlarına (writlere) dayanması mümkün olmakla birlikte bu bağlantı ispatlanamamıştır. ${ }^{29} \mathrm{Bu}$ nedenle, tarihsel açıdan aslında çok net bir geçmişe sahip değildir.

Zorlayıc1 emir konusunda belirleyici dava, 1615 tarihli Bagg davasıdır. ${ }^{30}$ Bagg, Plymouth kasabasında bir amirdir ve görevine yakışmayan davranışları sebebiyle görevinden alınmıştır. Bagg'in başvurusu üzerine, mahkeme, savunması alınmayarak görevinden alındığı ve haklarından mahrum bırakıldığ 1 gerekçesiyle görevine iade edilmesine karar vermiş ve bu konuda zorlayıcı bir yargısal emre hükmetmiştir. ${ }^{31} \mathrm{Bu}$ davada, Lord Mansfield zorlayıc1 yargısal emri şu şekilde ifade etmiştir: "Zorlayıcı emir, hukuka aykırılık ve kolluğun kusuru sebebiyle oluşacak düzensizlikleri engelleme amacıyla ortaya çıkmıştır. Özel bir hukuki çarenin öngörülmediği ancak adalet ve iyi yönetim ilkelerinin bunu gerektirdiği her durumda kullanılmalıdır." ${ }^{32} \mathrm{Bu}$ kararın ardından pek çok davada zorlayıcı emir kullanılmıştır. Ancak 19. yüzyıldaki yerel yönetimler reformu ile zorlayıcı emre olan ihtiyaç azalmış ve istinaf gibi alternatif kanun

25 Edward King/Joseph Hawley, “İngiliz (Common Law)'unun Gelişmesi”, Çev. İlhan LÜTEM, 16(1-4), Ankara Üniversitesi Hukuk Fakültesi Dergisi, s. 221; Burak Açdoyuran, "İngiltere'de İdarenin Yargısal Denetiminde Mahkemelere Tanınan Ayrıcalıklı Emir (Prerogative Remedy) Verme Yetkisi”, 1999, 1(3), Selçuk Üniversitesi Sosyal Bilimler Meslek Yüksek Okulu Dergisi, s. 185.

26 Mark Elliott/Jason N. E. Varuhas, Administrative Law Text and Materials, 5th Edition, Oxford, 2017, s. 453.

27 Elliott/Varuhas, s. 463.

28 Düğer, s. 199.

29 Craig, s. 801.

30 Craig, s. 801; Bagg davasından önce, 1573 yılında Middleton Davası ile zorlayıcı yargısal emre benzer bir kararın verildiği ve bu davada da rapor edilmemiş bir davaya, Anable Davası'na, atıf yapıldığı görülmektedir. Bkz. Avc1, s. 172; Aydar, s. 74.

31 Craig, s. 801; Avc1, s. 172.

32 Craig, s. 801. 
yolları ortaya çıkmıştır. ${ }^{33}$

Zorlayıc1 emrin verilebilmesi için Mahkemeler ve İnfaz Kanunu'nun 15. maddesinde iki şart aranır. Aranan ilk şart gereği; emrin amacı bir kamu görevinin yerine getirilmesini sağlamak olduğundan, öncelikle ortada bir kamu görevi olmalıdır. ${ }^{34} \mathrm{Bu}$ kamu görevinin, başvuru sahibine ya da onun içinde bulunduğu bireylere karşı idarenin bir görevi olması gerekir. ${ }^{35} \mathrm{Kamu}$ görevinin Common Law ya da kanundan kaynaklanmas1 mümkündür. ${ }^{36}$ Aranan bir diğer şart, başvurucunun yapılmasını istediği işlem ya da eylemin gerçekleştirilmesini ilgili idareden talep etmesidir. ${ }^{37} \mathrm{Bu}$ talebin reddedilmesi veya reddedilmiş sayılması halinde, mahkeme zorlayıc1 emre hükmedebilecektir. İdare tarafından cevap verilmemesi, başvurunun kabulünün hukuka aykırı şartlara bağlanması ya da belirsiz cevap verilmesi hallerinde ise talep reddedilmiş sayılacaktır. ${ }^{38}$

Prohibiting order (prohibition; yasaklayıc1 emir), idarenin hukuka aykırı davranmasını engellemek adına, idari işlem yapılmadan evvel verilen emir türüdür. Alt dereceli mahkemelerin, bakanların ya da kamu kuruluşlarının yetki aşımlarını engelleyici nitelikte bir yargısal emirdir. ${ }^{39}$ Bilindiği üzere, denetim yolları genel olarak yetki aşımı (ultra vires) sebebiyle ortaya çıkmıştır. ${ }^{40}$ Yasaklayıcı emir, henüz yetki aşımı gerçekleşmemişken bu ihtimali engelleyen bir yargısal denetim yolu olarak öngörülmüştür. Zorlayıcı emirde kamu görevlerinin yerine getirilmesi için emir verilmekteyken, yasaklayıcı emirde hukuka aykırılık teşkil edeceğinden idareye ait işlem engellenmektedir. Gerçekleşmeden önce hukuka aykırı hareketin engellenmesi sağlanmaktadır. ${ }^{41}$

\footnotetext{
33 Craig, s. 801.

34 Craig, s. 801 vd; Aydar, s. 76; Avc1, s. 174.

35 Craig, s. 802; Aydar, s. 76;

36 Avc1, s. 171; Düğer, s. 200.

37 Aydar, s. 80; Bu şartın geleneksel görüş bakımından geçerli olduğu ve günümüz şartlarında aranması gerekmeyeceğine ilişkin görüş için bkz. Craig, s. 803; Avcı'ya göre aranan ikinci şart, zorlayıcı yargısal emrin uygulanmasından önce ilgili idareden söz konusu görevin icrasının istenmesi ve bu talebin idare tarafından reddedilmesidir. Bizim ayrı ayrı belirttiğimiz ilk iki şartı, yazar birlikte değerlendirmektedir. Avc1, s. 174.

38 Aydar, s. 81; Avc1, s. 174.

39 Avc1, s. 170.

40 Craig, s. 16 vd.

41 Elliott/Varuhas, s. 463.
} 
Yasaklayıc1 emre önemli bir örnek, $R v$. Liverpool Corporation, ex parte Liverpool Taxi Fleet Operators'Association davasıdır. İlgili davada mahkeme, bir yerel yönetime ait yeni taksi ruhsatı verilmesi işleminin, mevcut taksi şoförlerinin ya da temsilcilerinin görüşleri alınmaksızın gerçekleştirilmesini yasaklamıştır. Lisans sayısını bir süreliğine 300 olarak sınırlamıştır. ${ }^{42}$ Bir başka örnekte ise, mahalli bir idarenin film lisansı verirken uyguladığı hatalı ölçütü engellemek amaciyla yasaklayıcı emre hükmetmiştir. ${ }^{43}$ Yasaklayıcı emir idarelere karşı verilebileceği gibi, mahkemelere karşı da verilebilir; tıpk1 diğer yargısal emir türleri gibi. Örneğin, $R$. v. Kent Police Authority, ex parte Godden davasında, daha önce aynı davada taraf konumunda olan doktorun tarafsız olamayacağı nedeniyle, bilirkişi olarak değerlendirme yapması Yüksek Mahkemece yasaklanmıştır. ${ }^{44}$ Alt mahkemenin bu yönde verebileceği karar, hukuka aykırılık oluşturacağından dolayı yasaklayıcı emirle engellenmiştir.

Quasing order (certiorari; iptal emri), hukuka aykırı kararların geçmişe etkili biçimde ortadan kaldırılmasını sağlayan emir türüdür. Bozucu emir olarak da adlandırılabilir. Bu emir, yargısal denetimde en çok başvurulan yoldur. ${ }^{45}$ Doktrinde yer alan bir ifadeye göre; "Bir kamu idaresinin yetkilerini, yetki dışı ya da kötüye kullandı̆̆l, ya da doğal adalet kurallarına aykırı, ya da yasa hatasi yaparak kullandiğ hallerde certiorari yoluyla idari karar iptal edilir." ${ }^{46} \mathrm{Bu}$ ifadeden çıkarılan sonuca göre, iptal emrinin üç türü söz konusudur: Maddi yetki aşımı, usuli yetki aşımı ve hukuki hata. ${ }^{47} \mathrm{Bu}$ üç halden birinin varllğında, başvuru üzerine mahkeme işlemin iptaline yönelik yargısal emre hükmedecektir.

İptal emrinin verilmesi ile mahkeme kararının zorla kabul ettirilmesi değil, hukuka aykırı bir kararın iptal edilmesi söz konusudur. İptal emri, hukuka aykırılığın ortadan kaldırılmasını amaçlar. Dolayısıyla yargısal denetimin önemli bir parçasıdır. İdareye yeniden ve hukuka uygun bir işlem yapma olanağı yaratılmaktadır. İptal emrinde, ya yetki olmadan işlem yapılmış

42 Elliott/Varuhas, s. 463; Aydar, s. 88; Avc1, s. 171.

43 Aydar, s. 87.

44 Aydar, s. 87.

45 Bu durumu ifade eden Cocks v. Thanet Bölge Konseyi davasında, Lord Bridge iptal emrinin hukuka aykırılığın gözden geçirilmesinde birincil ve en uygun çözüm olduğunu söylemiştir. Elliott/Varuhas, s. 461.

46 Örücü, s. 263.

47 Avcı, s. 170; Açdoyuran, s. 187; Daha çok hukuki hataya ilişkin uygulandığı konusunda bkz. Craig, s. 794. 
veya mevcut yetki aşılmıştır ya da doğal adalet kuralları ihlal edilmiştir. İşlemi yapan iradede meydana gelen hile, yalan ya da zor kullanılması durumu iradeyi sakatlamakta ve işlemin hukuka aykırı hale gelmesine sebep olmaktadır. ${ }^{48}$ İptal emriyle bu durumların ortadan kaldırılması ve hukuka uygun biçimde bir işlemin yapılmasının sağlanması amaçlanmaktadır.

İdareye ait her işlem iptal emrine konu olmaz. ${ }^{49}$ Öncelikle aranan şart, işlemin hukuka aykırı olmasıdır. Hukuka uygun bir işlemin iptal emri ile ortadan kaldırılması, bozulması mümkün değildir. Tarihsel olarak bakıldığında, iptal emri kralın bilgi istemesi yolu olarak ortaya çıkmıştır. ${ }^{50}$ Kararın hukuka uygun ya da aykırı olduğunun krala bildirilmesi usulü olarak işlev görmüştür. Sonrasında ise mahkemeler tarafından idarelerin hukuka aykırı işlemlerinin iptal edilmesine evrilmiştir.

Zorlayıcı ve yasaklayıcı yargısal emirler ile iptal emri Kraliyete karşı verilemez. Kral fermanlarına (writlere) dayanan yargisal emirlerin Kraliyete karşı verilememesi anlaşılır bir düzenlemedir. Tarihsel olarak bu emirlerin as1l sahibi Kraliyettir. Öte yandan bu emirlerin, askeri konularda ve üst mahkemelere karşı verilmesi de mümkün değildir. ${ }^{51}$

Declaration (açıklama), hem kamu hukuku hem de özel hukuk alanında kullanılmaya uygun, esnek bir hukuki yol olup, çeşitli durumlarda taraflar arasındaki hukuki ilişkiyi göstermek amacıyla başvurulan yargısal bir yoldur. ${ }^{52}$ Yargısal denetim esnasında, diğer ayrıcalıklı emirler yanında declaration ile açıklayıcı bir hüküm tesis edilebilir. ${ }^{53}$ Örneğin, bir iptal emrine (quasing order) dayanak olarak, açıklamaya hükmedilebilir. ${ }^{54}$ Dikkat edilmelidir ki, açıklama aslında yargısal emir niteliğinde değildir. Bu husus doktrininde de savunma bulmuştur. ${ }^{55}$ Mahkeme tarafından uygulanacak kuralların açıklanması ya da taraflara haklarının açıklanmasından ibaret olup tamamen

\footnotetext{
48 Açdoyuran, s. 187.

49 "Britanya'da yetki onu kullananın kimliğine göre değil, kendi yapısına göre değerlendirilir." Örücü, s. 264.

50 Örücü, s. 264.

51 Clive Lewis, Judicial Remedies in Public Law, 3rd Edition, Sweet\&Maxwell, 2004, s. 226.

52 Düğer, s. 189 vd.

53 Kurt, s. 106.

54 Lewis, s. 206.

55 Düğer, s. 189.
} 
bir tespit hükmündedir; herhangi bir zorlayıc1lık içermemektedir. ${ }^{56}$ Hukuki etkisi doğrudan değil, dolaylıdır. Ancak yine de etkilidir. Çünkü idarelerin mahkemeye ait bu açıklayıcı hükmü dikkate almaması düşük bir ihtimaldir. ${ }^{57}$ Açıklamanın yargısal emir niteliğinde olmadığı kanaatimize rağmen yargısal emir türleri içerisinde belirtmemizin nedeni, Mahkemeler ve İnfaz Kanunu'nun ilgili 15. maddesinde sayılan yargısal emir türleri arasında yer almış olmasıdır.

Açıklama yoluna başvurabilmek için somut bir olayın varlığ 1 gerekir. ${ }^{58}$ Ancak somut, kesin ve yürütülebilir bir işlemin varllğı halinde, mevcut işleme ilişkin olarak kamu makamlarının yetkili olup olmadıkları ve işlemin hukuka uygun olup olmadığı mahkemece değerlendirilebilir ve bu doğrultuda bir açıklama yapılabilir. Açıklama, işlemin hukuka aykırılığını ya da yetki aşımı bulunup bulunmadığını tespit ve ifade eden bir karardır. Genel olarak, işlemin geçmişe etkili biçimde hukuka aykırılığını ortaya koyan açıklama, kimi zaman genel hukuk kurallarıyla geleceğe yönelik sonuçlar doğurucu biçimde kullanılabilir. ${ }^{59}$ Örneğin; yapılan hukuka aykırı düzenleyici bir işleme dayanan yeni işlemler yapılması açılama ile engellenebilir.

Injunction (olumlu ya da olumsuz mahkeme emri) (tam yargisal emir), mahkeme tarafindan idarelere veya alt mahkemelere bir yap ya da yapma emri verilmesini ifade etmektedir. Farklı bir ifadeyle, emredici ya da yasaklayıcı nitelikli mahkeme emridir. ${ }^{60}$ Özel hukuka ait bu yargısal emir türü kamu hukuku alanında da zamanla kullanılmaya başlanmıştır. 19. yüzyılın sonlarına kadar sadece yasaklayıcı nitelikte kullanılan injunction, sonrasında olumsuz/ yasaklayıcı ya da olumlu/emredici bir emir içerir nitelikte kullanılmıştır. ${ }^{61}$ Diğer yargısal emir türlerine nazaran daha çok tercih edilmektedir. Özel hukuk temelli bu yargısal emir türünün daha çok rağbet görmesinin nedeni, diğer yargısal emir türlerinin ihtiyaca cevap verememesi ve injunction türünün hem yap hem de yapma emrini içerebilen bir yargısal emir olmasıdır. ${ }^{62}$ Injunction hem zorlayıc1 emir (mandatory order) hem de yasaklayıc1 emir (prohibiting order) yerine kullanılabilir bir yargısal emir türüdür. Öte yandan injunction,

\footnotetext{
$56 \quad$ Avc1, s. 169.

57 Düğer, s. 190.

58 Açdoyuran, s. 190.

59 Craig, s. 812.

60 Garner, s. 904.

61 Açdoyuran, s. 188.

62 Aydar, s. 50.
} 
hukuka aykırı bir işlemin iptal edilene kadar yürütülmesinin durdurulmasını da öngörebilir. ${ }^{63}$ Belirli bir süre için ya da dava sonuçlanıncaya kadar belli bir durumun muhafazası için verilebilen ara karar niteliğinde bir emir türüdür. ${ }^{64}$

1977 yılında yapılan usul hukuku reformları ile tam yargisal emrin ${ }^{65} \mathrm{kamu}$ hukukundaki uygulaması ağırlık kazanmıştır. Öncesinde kamu otoritesinin yaptığı işlem veya eylemle belirli bir hakkı ihlal edilirse, yani özel bir hakk1 ihlale uğrarsa yargısal emir başvurusu yapabilmekteydi. Ancak reform sonrası hak ihlali değil menfaat ihlali yargısal emir başvurusu için yeterli kabul edilmeye başlanmıştır. ${ }^{66}$ Ehliyet şartının genişlemesiyle injunction başvuruları kamu hukuku alanında sık kullanılır hale gelmiştir. Injunction'ın bir diğer kullanım alanı ise, alt mahkemelerin görev alanları dışında kalan davaları görmelerinin önlenmesidir. Mahkemelerin yetkilerini aşarak görev alanları dışında kalan bir davayı görmesi bu yöntemle engellenebilmektedir. Ancak bu amaçla daha çok yasaklayıcı emir (mandatory order) yoluna başvurulduğunu belirtmek gerekir. ${ }^{67}$

Kraliyete karşı zorlayıcı ve yasaklayıcı emir gibi injunction da verilememektedir. Ancak bu yargısal emir türünün, Kraliyeti temsil eden memurlara karşı uygulanmasında bir engel bulunmamaktadır. 1994 tarihli $M$. v. Home Office davasında, mahkeme yürütmeye ilişkin görevlerin günümüzde Bakanlara ihdas edildiğini, Kraliyete verilmediğini ve bu nedenle tam yargısal emirlerin Kraliyeti temsil eden memurlara karşı uygulanabileceğini hükme bağlamıştır. ${ }^{68}$

\section{AMERÍKA BİRLEŞİK DEVLETLERI'NDE YARGISAL EMİR}

Anglosakson sisteminin bir diğer temsilcisi Amerikan hukuk sisteminde, kanuni düzenlemeler içtihatlar çerçevesinde yorumlanmaktadır. ${ }^{69}$ Mahkemeler

63 Avc1, s. 170.

64 Lewis, s. 278.

65 Injunction, hem emredici hem de yasaklayıcı mahkeme emrini kapsamaktadır. Bu nedenle tam yargisal emir olarak da ifade edilebilir.

66 Aydar, s. 94.

${ }^{67}$ Lewis, s. 279.

68 Lewis, s. 281 vd; Aydar, s. 98.

69 “Fransız İdare Hukuku'nun Conseil d'Etat'nın eseri olması gibi, Amerikan İdare Hukuku'nun da banisi yasama olsa bile, güncel durumuna ulaşmasında en büyük katkı, başta Yüksek Mahkeme olmak üzere genel anlamda yargınındır. Nitekim Amerika'da İdare Hukuku 'yönetimin denetlenmesi hukuku'dur. Aslında bu olgu bilindiği gibi Fransız İdare 
kanunları uygularken, ilgili mahkeme kararlarını inceleyip, ilgili hükmü uygulayan bir Anayasa Mahkemesi ya da temyiz mahkemesi kararı bulunup bulunmadığını tespit etme yükümlülüğündedirler. ${ }^{70}$ Common Law sistemine sahip olan Amerika Birleşik Devletleri, İngiliz krallarının memurlarına karşı uyguladığı yargısal emirleri yarg1 yetkisi içine dâhil etmiştir. Anayasal denetimin temeli sayılan Marbury v. Madison davasinda, yargisal denetimi harekete geçiren mekanizma bir yargısal emir türü olan mandamus yöntemi olmuştur. ${ }^{71}$ Yargısal emir ve İngiltere'de yargısal emirlerin hukuka uygunluk denetimde yer almasına olanak tanıyan Equity hukuku, Amerikan sistemini de aynı yönde etkilemiştir. ${ }^{72}$

İngiliz hukuk sisteminde olduğu gibi, Amerikan hukuk sisteminde de writler (kral fermanları) yer almaktadır. Örneğin, yasaların anayasaya uygunluğunun denetimi yolunu açan 24 Şubat 1803 tarihli Amerikan Yüksek Mahkemesi'nin Marbury v. Madison karar1, karardaki ifadesiyle writ (mahkeme emri) talebine ilişkin bir karardır. ${ }^{73}$ Amerikan sisteminin, yargıcın idareye yargısal bir emir vermesine müsaade ettiğini bu kararda görüyoruz. ${ }^{74}$ Marbury, yapılan ancak kendisine tebliğ edilmeyen atamasının kendisine tebliğine yönelik bir yüksek mahkeme emri (writ of mandamus) talep etmiştir. Atama işleminin tebliğinin yapılmasını, memura bir davranışın yapılması yönünde olumlu bir emir verilmesini talep etmiştir. Yüksek mahkeme, anayasaya aykırı bir yasaya dayanarak talepte bulunulduğundan bahisle, ilgili talebi reddetmiştir. ${ }^{75}$ Ancak hem asıl meselesi olan kanunların anayasaya

Hukuku için de geçerlidir ve İdare Hukuku'nun bir 'içtihat hukuku' olduğu şeklinde ifade edilir." İl Han Özay, "Komisyonlar Saltanatı Ülkesinin İdare Hukuku”, 1983, (1-3), İdare Hukuku İlimleri Dergisi, s. 101.

70 Şükrü Alparslan/Ümit Hergüner/Hülya Kızıler Kaledelen/Işı1 Ökten (Ed.), Amerika Birleşik Devletleri'nde Federal Yargılama Sistemi ve Bu Sistem İçinde Cezai Yargının Yeri ve İşleyişi, El Kitabı, E-kaynak için bkz. <https://photos. state.gov/libraries/turkey/231771/ PDFs/federal_yargi.pdf> Erişim Tarihi: 30 Ocak 2021, s. 11.

71 Güran, s. 195.

72 Güran, s. 195 vd.

$73<$ https://www.law.cornell.edu/supremecourt/text/5/137> Erişim Tarihi: 30 Ocak 2021; Davaya ilişkin bilgi için bkz. Turhan Feyzioğlu, Kanunların Anayasaya Uygunluğunun Kazai Murakabesi (Yabanc1 Memleketlerde-Türkiye'de), Ankara Üniversitesi Siyasal Bilgiler Yayınları No: 19-1, 1951, s. 164 vd; Kılınç, s. 144.

74 Güran, s. 195.

75 Marbury v. Madison davası, anayasa yargısının başlangıcı sayılan davadır. Konuya ilişkin detaylı bilgi için bkz. Kemal Gözler, Anayasa Hukukunun Genel Esasları, 10. Baskı, Ekin Yayınları, Ağustos 2018, s. 449 vd; Murat Sevinç, "Amerikan Yüce Mahkemesi”, 1996, 
uygunluğunun denetimi yolunu açması hem de Amerikan hukuk sisteminde yargısal emirlerin mevcudiyetini göstermesi bakımından karar önemlidir. Bizim açımızdan önem taşıyan boyutuyla karara göre, davacı atama kararının tebliğini talep edebilir, ortada bir hak ihlali vardır ve ilgili bakana, talep üzerine, mahkeme tarafindan bu yönde bir emir gönderilmesi mümkündür. ${ }^{76}$

Amerikan hukuk sisteminde kanunların yargısal denetiminin üç yolu mümkündür: Defi (itiraz yolu) ${ }^{77}$, injunction (yargisal emir) ve tespit kararları. ${ }^{78}$ Yargısal emir, Amerikan hukuk sisteminde kanunların yargısal denetimine imkân sağlayan bir denetim aracıdır. İngiliz hukukunda Common Law'un eksik kalan yönlerini tamamlamak üzere Equity (hakkaniyet) hukuku kapsamında uygulanan injunction, Amerikan hukukunda ise, anayasa yargıs1 alanında defi yoluyla denetimin eksikliklerini tamamlama veya sakıncalarını giderme vazifesi görmüş̧ür. ${ }^{79}$ Anayasaya aykırılı̆̆ın daha çabuk ortaya konmasını sağlamıştır. Injunction müessesesi ${ }^{80}$, hukuka uygunluğu sağlamada yapıcı ve etkili bir rol üstlenmiştir. $\mathrm{Bu}$ usulle, bir kanunun uygulanması beklenmeden, hukuka aykırı uygulanmasının uygulamadan önce engellenmesi sağlanmaktadır.

Injunction usulüne göre, bir kimse kendisine uygulanması muhtemel olan ve uygulandığ kanunun anayasaya aykırı olduğu iddiasıyla mahkemeye başvurabilmekte

51(1), Ankara Üniversitesi Siyasal Bilgiler Fakültesi Dergisi, s. 394 vd; Can Yavuz, “Amerika Birleşik Devletleri Yüce Mahkemesi”, Ocak-Şubat 2017, (128), Türkiye Barolar Birliği Dergisi, s. 459 vd; Eroğul, s. 89 vd.

76 Feyzioğlu, s. 167.

77 Amerika'da kanunların esas denetim yolu defi yoluyla denetimdir. Tarafların mahkemede ileri sürmesi ya da mahkemenin re'sen dikkate alması ile anayasaya aykırılık iddiası bir ön sorun yapılır. Sadece tarafların ileri sürmesi ile değil, mahkemenin re'sen dikkate alması ile de kanunun anayasaya aykırılığı dikkate alınabildiğinden bu denetim yolunu, Anayasa hukuku bakımından, defi değil "itiraz yolu" olarak değerlendirmek daha doğrudur. Erdoğan Teziç, Anayasa Hukuku, 19. Bası, Beta Yayınları, 2015, s. 247; Yılmaz Aliefendioğlu, Anayasa Yargısı ve Türk Anayasa Mahkemesi, Yetkin Yayınları, 1996, s. 58, dn.23.

78 Yargısal emir (injunction) ve tespit kararları (declaratory judgement) itiraz yolu dışında geliştirilmiş, koruyucu tedbirlerdir. Teziç, s. 248; Feyzioğlu, s. 183.

79 İtiraz yolu ile kanunların denetiminde, karar alınıp kesinleşinceye kadar telafisi güç zararlar meydana gelebilir. Ya da bir kanun anayasaya aykırı olduğu halde herhangi bir davaya konu olmadıkça denetime imkan olmayabilir. Bu gibi durumlarda injunction (yargısal emir) yolu, denetimi mümkün kılmaktadır. Bkz. Feyzioğlu, s. 186.

80 Teziç, injunction'1 “kanunların yürürlüğünün durdurulması niteliğinde kararlar” olarak ifade etmiştir. Teziç, s. 248. 
ve mahkemeden kanunun uygulanmaması yönünde bir yargısal emir talep edebilmektedir. Mahkeme talebi haklı bulursa, gereğine göre kanunu uygulamakla yükümlü memurlara yönelik olumlu ya da olumsuz yargisal emirler verebilmektedir. ${ }^{81}$ Sonuçları bakımından benzememekle birlikte ${ }^{82}$, başvuru usulü bakımından Amerikan hukukundaki yargısal emir başvurusunun idari yargıda yer alan iptal başvurusuna benzediğinden bahsetmek mümkündür. Kanunun anayasaya aykırı olduğu gerekçesiyle yargısal emir talebinde bulunabilecek kişiler, kanunun kendisine uygulanması muhtemel olan kişilerdir. Bu usul, iptal davasındaki menfaat ihlali şartını anımsatmaktadır.

Görüldüğü üzere, yargısal emir müessesesinin Amerikan hukukunda önemi büyüktür. Kanunların denetiminde üstlendiği rol, keyfi olarak bu kararın verilmemesini gerektirir. $\mathrm{Bu}$ nedenle, bu kararları üç hâkimli mahkemeler verebilmekte ve kararlar aleyhine doğrudan doğruya Yüksek Mahkemeye başvurulabilmektedir. ${ }^{83}$

\section{FRANSA'DA YARGISAL EMIIR}

Yargısal emir, 8 Şubat 1995 tarihli "Mahkemelerin Kuruluşu, Medeni Usul, Ceza Usulü ve İdari Yargılama Usulüne İlişkin 95-125 sayılı Kanun” ile Fransız hukukunda yer almaya başlamıştır. ${ }^{84}$ Bu yasayla yapılan değişiklik, bir reform, bir tabunun yıkılışı, idari yargıda bir devrim olarak nitelendirilmiştir. ${ }^{85}$ $\mathrm{Bu}$ yasadan önce, idari yargıcın gerçek yetkisini kullanmak için yargısal emir

81 Yargisal emir olumlu yönde ise, yani bir hususun yerine getirilmesine yönelikse writ of mandamus'tan bahsedilir. Örneğin, anayasaya aykırı bir kanuna dayanarak tahsil edilen verginin mükellefe iadesine yönelik emir bu yöndedir. Kanunun anayasaya aykırı olduğu ve bu nedenle uygulanmaması gerektiği yönündeyse olumsuz bir emirden bahsedilir. Bunlar ise writ of prohibition (yasaklayıcı emirler) olarak adlandırılmaktadır. Feyzioğlu, s. 187; Teziç, s. 249.

$82 \mathrm{Bu}$ başvuru sonucunda kanun varlığını korumaya devam etmektedir. Ancak uygulamakla görevli memurlar tarafından artık fiilen uygulanmamaktadır. Hukuken varlığını sürdüren ancak fiilen uygulanmayan kanunu kaldırmak, işlemlerdeki paralellik ilkesi gereğince yasama organının yetkisindedir. Teziç, s. 248.

83 Feyzioğlu, s. 190.

84 Aydın Gülan, “Fransa'da İdari Yargının Etkinliğini Sağlama Arayışları”, İdari Yargının Yeniden Yapılandırılması ve Karşılaştırmalı İdari Yargılama Usulü, Danıştay ve İdari Yargı Günü 133. Yıl Sempozyumu, Danıştay Tasnif ve Yayın Bürosu Yayınları No: 63, Ankara, 11-12 Mayıs 2001, s. 25 vd.

85 Roland Debbasch, "Le juge Administratif et L'injonction: La Fin d'un tabou”, La Semaine Juridique, 1996, No. 16, s. 161 vd. 
vermekten kaçınmaması gerektiği Fransız doktrininde savunulmuştur. ${ }^{86}$ İdari yargıcın yargısal emirden kaçınmasının yargıcın kendi kendine dayattığ bir yasak olduğu, yargıcın kendi kendini yaraladığı ve sahip olduğu gücü kullanmadığ 1 savunulmuştur. ${ }^{87}$ Doktrinde yargısal emrin idari yargıcın kararlarını uygulatma ihtiyacını karşılayan ve fakat idarecinin yerine geçme amacı taşımayan bir yetki olduğundan bahsedilmiştir. ${ }^{88}$ Yargısal emir, yargıcın bir fonksiyon gaspıyla idareci yerine geçmesinin yolu değil, kararların uygulanmasını güvence altına alma yoludur.

Fransa'da yargısal emir kavramının ortaya çıkışı, Conseil d'Etat'nın 1889 tarihli Cadot kararına kadar götürülmektedir. ${ }^{89} \mathrm{Bu}$ karar ile mahkeme, önüne gelen uyuşmazlığı doğrudan karara bağlamış ve bakan-hakim teorisinden tamamen ayrılmıştır. Karar, idari yargının sürekli güçlendiği tarihsel süreç bakımından bir dönüm noktasıdır. Öte yandan idari kararlara karşı yarg1 yolunun açık olduğu ilkesinin de temeli sayılır. ${ }^{90}$

Conseil d'Etat'nın yargısal emre ilişkin bir diğer önemli içtihadı, astreinte yetkisinin kabulünü içeren 16 Mayıs 1974 tarihli Barre et Honnet kararıdır. ${ }^{91}$ Bu kararda, mahkeme kararının uygulanmaması karşısında öngörülen parasal cezanın vazgeçilmez bir tedbir olduğu vurgulanmıştır. ${ }^{22}$ Astreinte yetkisinin, yargıcın, almış olduğu kararların uygulanması için gerekli maddi yaptırımlara hükmedebilmesini içerdiği ifade edilmiştir.

Astreinte, mahkeme kararının uygulanmadığı her gün başına kararı uygulamayan kamu görevlisine kesilen parasal cezadır. ${ }^{93}$ Astreinte, 16

\footnotetext{
${ }^{86}$ Aktaran Yaşar, s. 166.

87 Camille Broyelle, "Le pouvoir d'injonction du juge administratif", 2015, (3), RFDA, s. 441.

88 Aktaran Yaşar, s. 184.

89 CE, 13 Décembre 1889, Cadet, Recueil Lebon, 1889, s. 1148, <www.conseil-etat.fr > Erişim Tarihi: 22 Ocak 2021; Yaşar, s. 164.

90 Conseil d'Etat'nın Cadot kararına ilişkin açıklama için bkz. <https://www.conseil-etat.fr/ ressources/decisions-contentieuses/les-grandes-decisions-du-conseil-d-etat/conseil-d-etat13-decembre-1889-cadot> Erişim Tarihi: 22 Ocak 2021; Erkut, "Gelişim”, s. 50.

91 Karar metni için bkz. <https://www.legifrance.gouv.fr/affichJuriAdmin.do?idTexte=CETA TEXT000007641774> (Erişim Tarihi: 22 Ocak 2021; Daniel Labetoulle, "De l'astreinte à l'injonction: Retour sur une évolution", 2015, (3), RFDA, s. 456 vd.

92 Franck Modern, "İdari Yargıcın Yeni Emir Verme (Injonction) Yetkisi Üzerine", Çev. Ramazan Çağlayan, 2004, 8(1-2), Atatürk Üniversitesi Erzincan Hukuk Fakültesi Dergisi, s. 656.

93 Chapus, s. 1206.
} 
Temmuz 1980 tarihli kanunla ${ }^{94}$ sadece Conseil d'Etat'ya tanınan bir yetkiydi. ${ }^{95} \mathrm{Bu}$ kanunla yargıç, almış olduğu kararların uygulanması için gerekli maddi yaptırımlara hükmedebilme yetkisini kazanmıştı. 8 Şubat 1995 sayılı "Mahkemelerin Kuruluşu, Medeni Usul, Ceza Usulü ve İdari Yargılama Usulüne İlişkin 95-125 sayılı Kanun", bu yetkiyi bölge idare mahkemesi ve idare mahkemesi yargıçlarına da tanımıştır.

1995 tarihli “Mahkemelerin Kuruluşu, Medeni Usul, Ceza Usulü ve İdari Yargılama Usulüne İlişkin 95-125 sayılı Kanun" ile mahkemelere genel olarak yargısal emir verme, yani injonction yetkisi tanınmıştır. Örneğin, Lille idare mahkemesi 26 Mayıs 1995 tarihli kararı ile okuldan kaydı silinen öğrencinin tüm haklarıyla birlikte yenden kaydının yapılmasına karar vermiştir. ${ }^{96}$ Kanunun kabulünden kısa süre sonra Lyon idare mahkemesince, inşaat ruhsatı talebinin reddi kararına karşı açılan davada, ruhsatın reddi kararının hukuka aykırılığına karar vermekle yetinmemiş, ruhsatın üç ay içerisinde verilmesine de hükmetmiştir.97

1995 tarihli "Mahkemelerin Kuruluşu, Medeni Usul, Ceza Usulü ve İdari Yargılama Usulüne İlişkin 95-125 sayılı Kanun"la yapılan değişiklikler "İdare ve Bölge İdare Mahkemeleri Kanunu"na işlenmiştir.98 "Kararların yerine getirilmesi" başl1klı bölümün L. 8-2. paragrafında şu ifadeler yer almaktadır:

"Mahkeme kararl, kamu tüzel kişisinin veya kamu hizmeti yürüten özel hukuk tüzel kişisinin, kararın uygulanmasına ilişskin belirli bir tedbiri almasını zorunlu kllyyorsa, bu hususta başvuruda bulunulan idare mahkemesi ya da

9416 Temmuz 1980 tarihli ve 80-539 sayılı "Kamu Hukuku Tüzel Kişileri Tarafından Mahkeme Kararlarının Uygulanması Ve İdari Konulardaki Para Cezalarının Ödenmesi Hakkındaki Kanun" metni için bkz. <https://www.legifrance.gouv.fr/affichTexte.do;jsessio nid=DB2AC2732985644BC75868162942FC7C.tpdjo04v 1?cidTexte=JORFTEXT000000 705334\&dateTexte $=20000412>$ Erişim Tarihi: 24 Ocak 2021; Bilgi için bkz. Labetoulle, s. $456 \mathrm{vd}$.

95 Astreinte yetkisine ilişkin bilgi için bkz. René Chapus, Droit du Contentieux Administratif, $13^{\text {eme }}$ Édition, Montchrestien, 2008, s. 194 ve 199; Labetoulle, s. 456 vd; Gilles Bardou, "Pouvoir d'injonction et exécution des décisions de justice", RFDA, 2015, (3), s. 452 vd.

96 Gülan, s. 30.

97 Gülan, s. 30.

986 Ocak 1986 tarihli ve 86-14 sayıll “İdare ve Bölge İdare Mahkemeleri Kanunu”nun ilgili maddeleri için bkz. <https://www.legifrance.gouv.fr/affichCodeArticle.do;jsessionid=2732 A33BF9FD0D5EF3DC74A8DDB15203.tplgfr22s_2?cidTexte=LEGITEXT000006071344 \&idArticle $=$ LEGIARTI000006560926\&dateTexte $=20200228 \&$ categorieLien $=$ id\#LEGIAR TI000006560926> Erişim Tarihi: 24 Ocak 2021. 
idari istinaf mahkemesi uygun tedbiri ve gerekli hallerde uygulama süresini aynı kararda belirtir./ Mahkeme kararı, kamu tüzel kişisinin veya kamu hizmeti yürüten özel hukuk tüzel kişisinin yapılacak bir araştırmadan sonra yeni bir karar almasını zorunlu kıllyorsa, bu hususta başvuruda bulunulan idare mahkemesi ya da idari istinaf mahkemesi, bu yeni kararin belirli bir süre içinde alınmasını aynı kararında hükme bağlar."

Yargisal emirle ilgili önemli bir başka düzenleme ise, 30 Haziran 2000 tarihli ve 2000-597 say1l “Idare Mahkemelerindeki Geçici Tedbirler Hakkında Kanun "99 ile İdari Yargılama Usulü Kanunu'na eklenen référé konusudur. Bu kapsamdaki kararlar, "Référé" başlığıyla 5. Kitap olarak Kanuna eklenen ve temel hak ve özgürlükleri koruma amacıyla acil durumlarda verileceği ifade edilen ihtiyati tedbir niteliğindeki kararlardır. ${ }^{100}$

Référélerin pek çok türü ve farklı adlandırmaları mevcuttur. ${ }^{101}$ Bizim açımızdan önem arz eden référé türü, "Référé Libérté"dir. ${ }^{102}$ Bunun nedeni, temel hak ve özgürlüklerin ihlali halinde söz konusu olan référé libérténin, içinde bir yargısal emir barındırmasıdır. Bu karar, ilgilisine bir yap emri vermektedir. Référé libérté başvurusu sonucu, yarg1 yerinin verdiği karar bir yargısal emir teşkil etmektedir. Temel hak ve özgürlüklere müdahale niteliğinde bir idari işlem ya da eylemin bulunması halinde, mahkemeden référé libérté talebinde bulunan kişi, mahkemenin vereceği yargısal emir

99 30.06.2000 tarihli ve 2000-597 sayıl1 "Iddare Mahkemelerindeki Geçici Tedbirler Hakkında Kanun" metni için bkz. <https://www.legifrance.gouv.fr/affichTexte.do?cidTexte=JORFTE XT000000204851\&categorieLien=id $>$ Erişim Tarihi: 24 Ocak 2021.

100 Référéler ihtiyati tedbir niteliğinde mahkeme kararlarıdır. Mahkemeler acil durumlarda bu tür kararlara hükmederler. Référélere ilişkin detaylı bilgi için bkz. Chapus, s. 1355 vd; Camille Broyelle, Contentieux Administratif, 6e édition, LGDJ, 2018-2019, s. 449 vd; Bahtiyar Akyılmaz/Murat Sezginer/Cemil Kaya, Türk İdari Yargılama Hukuku, Savaş Yayınevi, 2018, s. 669 vd.

101 Didier Truchet, Droit Administratif, $3^{e}$ édition, Thémis Droit, 2010, s. 139; Chapus, s. 1355 vd; Agatha Van Lang/ Geneviève Gondouın/Véronique Inserguet Brısset, Dictionnaire Du Droit Administrative, 7e Édition, LGDJ, Collection Dictionnaires Sirey, 2015, s. 396 vd.

102 Référé libérté için bkz. Chapus, s. 1423; Truchet, s. 140; Jeangırard-Dufal, s. 461 vd; Alix Perrın, "Au-Delà du Cadre Législatif İnitial: Le Pouvoir D'injonction en Dehors de La Loi Du 8 Février 1995", 2015, (4), RFDA, s. 643 vd; Référé türlerinden "Référé conservatoire/ Injonction" da anlam itibariyle emir içeren bir talebi ifade etmektedir. Ancak uygulamada bundan ziyade "Référé Libérté" kavramıyla karşılaşıldığından bu tür üzerinde açıklamalara yer vermekteyiz. Référé (seri yargılama) kurumuna ilişkin detaylı bilgi için bkz. Nazile İrem Yeşilyurt, "İdari Yargıda Yürütmenin Durdurulması ve İvedi Yargılama: Hukuka Sermayeye Koşut Hız Ayarı”, 2015, 70(2), Ankara Üniversitesi Siyasal Bilgiler Fakültesi Dergisi, s. 413 vd. 
neticesinde hak ihlalinden kurtulacaktır. Özgürlük kelimesiyle nitelenen bu tedbir türü, temel hak ve özgürlüklerle doğrudan ilişkilidir.

Fransız İdari Yargılama Kanunu, L. 521-2'ye göre; aciliyet gerekçesiyle yapılan bir talepte, bir kamu hizmetini yürütmekle sorumlu kamu tüzel kişisi ya da özel hukuk tüzel kişisinin yetkilerini kullanırken ciddi ve kanuna aykırı ihlallerde bulunması halinde, référé hâkimi temel hak ve özgürlügü korumak için gerekli olan her türlü tedbiri alabilir. ${ }^{103}$ Örneğin, kişinin pasaport talebi hukuka aykırı olarak reddedildiğinde, kişi temel hak ve özgürlüklerden biri olan seyahat özgürlüğünün ihlal edildiği gerekçesiyle mahkemeden 48 saat içerisinde ${ }^{104}$ karara bağlanmas1 gereken bir référé libérté talebinde bulunabilir. Bu talep, kişiye pasaport verilmesi talebini içerecektir. Yargı yeri, başvuran lehine vereceği bir kararla, ilgili idareye kişiye pasaport vermesini emredecektir. Dolayısıyla référé libérté sonucu alınan karar bir injonction, yargısal emir, teşkil edecektir. Bu durum pozitif düzenlemede yer alan yargısal emrin temel hak ve özgürlüklerin ihlal edildiği acil durumlarda kullanımına bir örnektir.

\section{IV. İTALYA'DA YARGISAL EMIR}

İtalyan Anayasa Mahkemesi tarafindan alınan 25 Haziran 1985 tarihli kararla, idare yargıcının, münhasır yetkiye sahip bulunduğu kamu personelinin mali haklarına ilişkin uyuşmazlıklarda yürütmenin durdurulması kararını verebilip, yargılama usulü yasalarının öngördüğ̈̈ ivedi diğer önlemleri kararlaştıramaması Anayasaya aykırı bulunarak iptal edilmiştir. ${ }^{105}$ Bunun üzerine, yargısal emir, 21 Temmuz 2000 tarihli ve 205 sayılı "İdari Yarg1 Konusunda Hükümler Kanunu" ile İtalyan idare hukukundaki yerini almıştır. ${ }^{106}$

2010 yılında ise, İdari Yargılama Usulü Kanunu (Code Of Administrative

103 Fransız İdari Yargılama Kanunu'nun konuyla ilgili madde metni için bkz. <https://www. legifrance. gouv.fr/affichCode.do;jsessionid=D32C3E2C10E8340EC5D56FC927A1D486. tplgfr23s_3?idSectionTA=LEGISCTA000006150399\&cidTexte=LEGITEXT00000607093 3\&dateTexte=20200224> Erişim Tarihi: 24 Ocak 2021.

104 Fransız İdari Yargılama Kanunu (CJA), L. 521-2: “... Référé hakimi 48 saat içerisinde kararını verir."

105 İl Han Özay, “İtalya: "Nakıs” İdari Rejim mi “Ma'kus Talih” mi?”, İdari Yargının Yeniden Yapılandırılması ve Karşılaştırmalı İdari Yargılama Usulü, Danıştay ve İdari Yargı Günü 133. Y1l Sempozyumu, Danıştay Tasnif ve Yayın Bürosu Yayınları No: 63, 11-12 Mayıs 2001, s. 20.

106 Özay, “İtalya: “Nakıs” İdari Rejim mi “Ma’kus Talih” mi?”, s. 18. 
Process) (CAP) yürürlüğe girmiştir. ${ }^{107}$ Kanunun 112. maddesinin ikinci fikrasında, idari yargıcın verdiği kararların kamu kurumları ve taraflarca uygulanmak zorunda olduğu belirtilmiştir. Maddenin ikinci fikrasında ise, mahkeme kararlarının uygulanmasına ilişkin dava açılması ele alınmıştır.

Kanunun 116. maddesinde, idari belgelere erişime ilişkin prosedür yer almaktadır. Bu maddede, kural olarak otuz günü geçmeyecek bir süre zarfında ve gerektiğinde ilgili usulleri dikte ederek talep edilen belgelerin verilmesi ve öngörüldügünde yayımlanması için hâkimin talimat verebileceği düzenlenmektedir. Kanunun 117. maddesinde idarenin sessiz kalmas1 karşısında yargılama düzenlenmiştir. Maddeye göre, dava basitleştirilmiş şekilde karara bağlanır ve kararın kısmi veya tamamen kabul edilmesi durumunda, hakim kural olarak 30 günü geçmeyecek şekilde gereğini yapmas1 için idareye talimat verir. Bu düzenleme IYYUK md. 28 ' de yer alan düzenleme benzeridir.

Kanunun 118. maddesinin başlı̆̆ “yargısal emir"dir (decreto ingiuntivo). "Ivedi yargllama velveya acil durumlarda hak sahibinin talep edebileceği ve mahkeme tarafindan hükmedilebilecek ihtiyati tedbirler" biçiminde tanımlanan yargısal emir kurumu, kanunda açıkça yer almaktadır ${ }^{108}$. İtalyan İdari Yargılama Usulü Kanunu'nda bu emir müessesesi yer almaktadır ve usulüne ilişkin olarak da Medeni Usul Kanunu'na atıf yapılmaktadır. ${ }^{109}$

Ad1 geçen düzenlemeler, ivedi yargılama usulü kapsamında olup, mahkeme tarafından verilen ihtiyati tedbir niteliğinde emirlerdir. Bu ihtiyati tedbirler farklı içeriklerde olabilir. Yargıç, karar verdiği davayı yeniden inceleyerek, verdiği karara ilişkin çeşitli emirler verebilir. ${ }^{110}$ Tazmin edilecek tutarın ödenmesine ilişkin emir verebilir ya da duruma göre alınması gereken geçici önlemlere hükmedebilir. ${ }^{111} \mathrm{Bu}$ kararlar, tazminat emri gibi uyulması

${ }^{107}$ Bilgi için bkz. <https://www.aca-europe.eu//en/eurtour/i/countries/italy/italy_en.pdf> Erişim Tarihi: 30 Ocak 2021.

${ }^{108}$ Kanun metni için bkz. <https://www.giustizia-amministrativa.it/il-codice-del-processoamministrativo-commentato> Erişim Tarihi: 30 Ocak 2021.

${ }^{109}$ Kanun metni için bkz. <https://www.studiocataldi.it/codiceproceduracivile/ codicediproceduracivile.pdf> Erişim Tarihi: 30 Ocak 2021.

110 Avrupa Konseyi'nin “Avrupa'da İdari Yargı: İtalyan İdare Hukuku Raporu” için bkz. $<$ http://www.aca-europe.eu/en/eurtour/i/countries/italy/italy_en.pdf > s. 20, Erişim Tarihi: 31 Ocak 2021.

111 Avrupa Konseyi’nin “Avrupa'da İdari Yarg1: İtalyan İdare Hukuku Raporu” için bkz. <http:// www.aca-europe.eu/en/eurtour/i/countries/italy/italy_en.pdf> s. 20, Erişim Tarihi: 31 Ocak 2021. 
zorunlu mahkeme kararlarıdır.

\section{SONUÇ}

Yargisal emir, hem Anglosakson hem de Kita Avrupası hukuk sistemine sahip ülkelerde var olan bir hukuki müessesedir. İlk uygulaması, İngiltere'de writ (kral fermanları) ile olmuştur. Anglosakson hukuk sisteminin bir diğer üyesi Amerika Birleşik Devletleri'nde ise, anayasa yargısının doğumu sayılan Marbury v. Madison davası ile gündeme gelmiştir. Ardından Kıta Avrupası'nda Fransa'yla başlayan yargısal emir uygulaması İtalya gibi diğer ülkelerde de yer almaya başlamıştır.

İngiltere'de kral fermanları döneminde, kralın memurlara ve mahkemelere yapması gerekenleri bildirdiği emirler olarak uygulanmaya başlayan bu müessese, günümüzde yargı yerlerinin verdikleri kararlara uyulmasını sağlama amaciyla uygulanmaktadır. Hukuk devleti ya da Anglosakson sistemindeki ifadesiyle hukukun üstünlügü ilkeleri gereği mahkemelerce verilen kararların uygulanması zorunludur. Mahkeme kararları, derhal uygulanma emrini içinde barındırmaktadır. Fakat uygulamada bu durum göz ardı edilmekte ve mahkeme kararları özüne aykırı olarak uygulanmayabilmektedir.

Yargısal emrin çalışmamızda yer verdiğimiz ülkelerdeki örnekleri, birtakım farklılıklar içermekle birlikte, genel olarak mahkeme kararlarının uygulanmasını amaçlamaktadır. Özellikle Fransa ve İtalya örneklerinde bu amaç daha belirgindir. Fransa'da yer alan astreinte, yargıcın almış olduğu kararların uygulanması için gerekli maddi yaptırımlara hükmedebilmesi yetkisini ifade eder. Yargıç bu yetkiyle, mahkeme kararlarının uygulanmasını güvenceye alan bir emre hükmeder. Fransa'da yargı kararlarının uygulanmasını sağlama yanında, temel hak ve özgürlüklerin korunması amacıyla acil durumlarda da yargısal emir uygulama alanı bulmaktadır (Référé libérté). İtalya'da ise, mahkeme kararlarının uygulanmasına ilişkin bir dava açılması imkânı ilgili kanunda düzenlenmiştir.

İngiltere'de, idarelerin işlem yapabilmesi mahkemeler tarafindan bir yetki tanınmasına bağlı olduğundan, yargısal emir müessesesi daha çok bu anlamda kullanılmıştır. İngiltere'de Common law'un eksik yönlerini tamamlamak üzere Equity hukuku kapsamında uygulanmaya başlayan yargısal emir, Amerika'da anayasal denetimde def'i yönteminin eksiklik yönlerini tamamlamak üzere kullanılmıştır. Amerika'da, kişiler kendilerine uygulanması muhtemel olan ve uygulandığı takdirde telafisi imkânsız zararlar 
doğuracak olan bir kanunun anayasaya aykırı olduğu iddiasıyla mahkemeye başvurabilmekte ve kanunun kendilerine uygulanmasını engelleyici yönde bir yargisal emir talep edebilmektedirler.

Türk hukukunda pozitif bir düzenlemeye sahip olmayan yargısal emir müessesesi, uygulandığı ülkelerde sahip olduğu işlevler göz önüne alındığında Türk hukuku bakımından incelenmeye değerdir. $\mathrm{Bu}$ inceleme, Türk hukukunda yargısal emre benzer nitelikte olan kimi mahkeme kararlarının nitelendirilmesine 1 şı tutacaktır.

Farklı ülkelerde yer alan uygulamalar değerlendirildiğinde yargısal emrin hukuk devleti ilkesine hizmet eden bir müessese olduğu açıkça görülmektedir. Türk hukukunda müessesenin uygulanabilirliğine ilişkin kanaatimiz, herhangi bir yasağın söz konusu olmadığ 1 yönündedir. Mahkemeler tarafından idarelere karşı, kararların uygulanmasını somutlaştırmak adına verilen bu tür kararlar Anayasamıza göre herhangi bir hukuka aykırılık yaratmamaktadır. Çünkü ortada kuvvetler ayrılığına aykırı bir uygulama yoktur. Yargı organı yargısal emir ile idare adına işlem ve eylem yapmamakta, yalnızca somut kararlar aracılığılla idarelere yol göstermektedir. Verdiği yargısal emirlerle, hukuka uygunluk sınırları içerisinde idareye işlemi nasıl yapması gerektiğini göstermektedir. Bu nitelikleri gereği, yargısal emir uygulamasına Türk hukuku açısından olumlu yaklaşılması gerektiği kanaatindeyiz. Hukuk devleti ilkesine hizmet eden oldukça işlevsel ve faydalı bir müessese olacaktır.

\section{KAYNAKÇA}

Açdoyuran B, "İngiltere'de İdarenin Yargısal Denetiminde Mahkemelere Tanınan Ayrıcalıklı Emir (Prerogative Remedy) Verme Yetkisi”, 1999, 1(3), Selçuk Üniversitesi Sosyal Bilimler Meslek Yüksek Okulu Dergisi, s. 183-194.

Akyılmaz B/Sezginer M/Kaya C, Türk İdare Hukuku, 10. Baskı, Savaş Yayınevi, 2019.

Akyılmaz B/Sezginer M/Kaya C, Türk İdari Yargılama Hukuku, Savaş Yayınevi, 2018.

Aliefendioğlu Y, Anayasa Yargısı ve Türk Anayasa Mahkemesi, Yetkin Yayınları, 1996. 
Alparslan Ş/Hergüner Ü/Kızıler Kaledelen H/Ökten I (Eds.), Amerika Birleşik Devletleri'nde Federal Yargilama Sistemi ve Bu Sistem İçinde Cezai Yargının Yeri ve İşleyişi, El Kitabı, < https://photos. state.gov/libraries/ turkey/231771/PDFs/federal yargi.pdf> Erişim Tarihi: 30 Ocak 2021.

Avc1 A, "İngiliz Hukukunda Mandamus (Mandatory Order) İlkesi”, 2014, 4(2), Hacettepe Hukuk Fakültesi Dergisi, s. 165-179.

Avrupa Konseyi'nin “Avrupa'da İdari Yargı: İtalyan İdare Hukuku Raporu”, $<$ http://www.aca-europe.eu/en/eurtour/i/countries/italy/italy_en.pdf,> Erişim Tarihi: 31 Ocak 2021.

Aydar H S, İngiliz Hukukunda Yargısal Emir Kavramı ve Türkiye'de Uygulanabilirliği, Yayımlanmamış Doktora Tezi, Anadolu Üniversitesi Sosyal Bilimler Enstitüsü, 2008.

Bardou G, "Pouvoir d'injonction et exécution des décisions de justice", 2015, (3), RFDA, s. 452.

Broyelle C, Contentieux Administratif, 6édition, LGDJ, 2018-2019.

Broyelle C, "Le pouvoir d'injonction du juge administratif", 2015, (3), RFDA, s. 441.

Candan T, "İdari Yarg1 Kararlarının Uygulanması-IV", 1991, (256), Maliye Postası Dergisi, s. 45-49.

Candan T, "Britanya İdari Mahkemeleri”, 1992, (4), Türkiye Barolar Birliği Dergisi, s. 485-510.

Chapus R, Droit du Contentieux Administratif, $13^{\mathrm{eme}}$ Édition, Montchrestien, 2008.

Craig P, Administrative Law, 8th Edition, Sweet\&Maxwell, 2016.

Debbasch R, "Le juge Administratif et L'injonction: La Fin d'un tabou”, 1996, No. 16, La Semaine Juridique, s. 161-167.

Duran L, İdare Hukuku Ders Notları, Fakülteler Matbaası, 1982.

Düğer S, Anglosakson Hukuk Sisteminde İdarenin Yargısal Denetimi, Yetkin Yayınları, Mart 2019. 
Elliott M/Varuhas J N E, Administrative Law Text and Materials, 5th Edition, Oxford University Press, 2017.

Eroğul C, Çağdaş Devlet Düzenleri, 10. Bask1, İmaj Yayınevi, 2016.

Feyzioğlu T, Kanunların Anayasaya Uygunluğunun Kazai Murakabesi (Yabancı Memleketlerde-Türkiye'de), Ankara Üniversitesi Siyasal Bilgiler Yayınlar1 No: 19-1, 1951.

Garner B A, Black Law Dictionary, 10th Edition, Thomson Reuters, 2014.

Gözübüyük Ş/Tan T, İdare Hukuku, Cilt I, 13. Bask1, Turhan Kitabevi, 2019.

Gözübüyük Ş, Yönetsel Yarg1, 35. Bas1, Turhan Kitabevi, 2016.

Gözler K, Anayasa Hukukunun Genel Esasları, 10. Baskı, Ekin Yayınları, Ağustos 2018.

Gülan A, "Fransa'da İdari Yargının Etkinliğini Sağlama Arayışları", İdari Yargının Yeniden Yapılandırılması ve Karşılaştırmalı İdari Yargılama Usulü, Danıştay ve İdari Yargı Günü 133. Yıl Sempozyumu, Danıştay Tasnif ve Yayın Bürosu Yayınları No: 63, 11-12 Mayıs 2001, s. 23-39.

Günday M, İdare Hukuku, 10. Baskı, İmaj Yayınevi, 2011.

Güran S, "Anayasa'nın Kuvvetler Ayrılı̆̆ı İlkesine ve Yönetim Yarg1 İlişkilerine Bakış Açısında Değişiklik", 1994, 11, Anayasa Yargısı Dergisi, s. 191-200.

Jeangirard-Dufal C, "Le juge administratif et l'injonction: Expérience de vingt années d'application", 2015, (3), RFDA, s. 461.

Karahanoğulları O, İdarenin Hukukla Kavranması: Yasallık ve İdari İşlemler (Yarg1 Kararlarına Dayalı Bir İnceleme), 3. Bas1, Turhan Kitabevi, 2015.

Kılınç B, "Common Law (Ortak Hukuk) Sistemine Sahip Ülkelerden A.B.D. ve İngiltere'de Anayasa Kavramı Ve Yargısal Denetim”, Anayasa Yargıs1 İncelemeleri-1, Anayasa Mahkemesi Yayınları, 2006, s. 113-148.

King E/Hawley J, “İngiliz (Common Law)'unun Gelişmesi”, Çev. İlhan LÜTEM, 1959,16(1-4), Ankara Üniversitesi Hukuk Fakültesi Dergisi, s. 178-233. 
Kurt S, "Britanya İdari Yargı Yerleri (Tribunal Sistem) ve Yargisal Denetim", 2004, (107), Danıştay Dergisi, s. 73-126.

Labetoulle D, "De l'astreinte à l'injonction: Retour sur une évolution", 2015, (3), RFDA, s. 456.

Lewis C, Judicial Remedies in Public Law, 3rd Edition, Sweet\&Maxwell, 2004.

Modern F, “İdari Yargıcın Yeni Emir Verme (Injonction) Yetkisi Üzerine”, Çev. Ramazan Çağlayan, 2004, 8(1-2), Atatürk Üniversitesi Erzincan Hukuk Fakültesi Dergisi, s. 651-675.

Mumcu U, “İngiliz Hukukunda Ultra Vires Kavramı”, 1970, XXVII, Ankara Üniversitesi Hukuk Fakültesi Dergisi, s. 37-66.

Onar S S, İdare Hukukunun Umumi Esasları, Cilt III, 3. Bas1, İsmail Akgün Matbaas1, 1966.

Örücü E, “Büyük Britanya'da İdarenin Yargısal Denetimi”, II. Ulusal İdare Hukuku Kongresi, İdari Yargının Dünyadaki Bugünkü Yeri, 1993, s. 254-270.

Özay İ H, Günışığında Yönetim II Yargısal Korunma, On İki Levha Yayıncılık, 2010.

Özay İ H, "İtalya: "Nakıs” İdari Rejim mi “Ma’kus Talih" mi?”, İdari Yargının Yeniden Yapılandırılması ve Karşılaştırmalı İdari Yargılama Usulü, Danıştay ve İdari Yargı Günü 133. Yıl Sempozyumu, Danıştay Tasnif ve Yayın Bürosu Yayınları No: 63, 11-12 Mayıs 2001, s. 17-22.

Özay İ H, "Komisyonlar Saltanatı Ülkesinin İdare Hukuku", 1983, (1-3), İdare Hukuku İlimleri Dergisi, s. 95-103.

Özbudun E, “İngiliz Hukukunda Hükümet Tasarrufları”, 1961, 18(1), Ankara Üniversitesi Hukuk Fakültesi Dergisi, s. 333-372.

Perrin A, “Au-Delà du Cadre Législatif İnitial: Le Pouvoir D'injonction en Dehors de La Loi Du 8 Février 1995”, 2015, (4), RFDA, s. 643.

Sarıca R, İdari Kaza, İ̈HHF Talebe Cemiyeti Yayınları, 1942.

Sevinç M, “Amerikan Yüce Mahkemesi”, 1996, 51(1), Ankara Üniversitesi 
Siyasal Bilgiler Fakültesi Dergisi, s. 391-407.

Teziç E, Anayasa Hukuku, 19. Bası, Beta Yayınları, 2015.

Truchet D, Droit Administratif, 3e édition, Thémis Droit, 2010.

Uler Y, İdari Yargıda İptal Kararlarının Sonuçları, AÜHF Yayınları, 1970.

Van Lang A/Gondouin G/Inserguet Brisset V, Dictionnaire Du Droit Administrative, ${ }^{7 e}$ Édition, LGDJ, Collection Dictionnaires Sirey, 2015.

Yaşar H N, İdari Yargı Kararlarının Etkinleştirilmesi Arayışında İdari Yargı İdari Yargıç Yargısal Emir, Tıpkı Basım, On İki Levha Yayıncılık, 2013.

Yavuz C, “Amerika Birleşik Devletleri Yüce Mahkemesi”, Ocak-Şubat 2017, (128), Türkiye Barolar Birliği Dergisi, s. 437-480.

Yeşilyurt N İ, "İdari Yargıda Yürütmenin Durdurulması ve İvedi Yargılama: Hukuka Sermayeye Koşut Hız Ayarı”, 2015, 70(2), Ankara Üniversitesi Siyasal Bilgiler Fakültesi Dergisi, s. 403-433. 